\title{
VEIKSNIAI, TURINTYS ITAKOS SVEIKŲ ŽMONIŲ KVĖPAVIMUI MIEGANT
}

\author{
ASTA JANUŠKEVIČIŪTÉ \\ PANEVĖŽIO APSKRITIES LIGONINÉ
}

Reikšminiai žodžiai: miegas, miego fazės, kvejpavimas, miego apnejja.

Santrauka. Miegas - periodiška sąlyginė ramybės būsena, kurios metu organizmas aktyviai atkuria jègas. Kai žmogus miega, susilpneja jo fiziologinès funkcijos, jis nemato ir negirdi, išnyksta sąmoningas psichikos aktyvumas. Miego metu keičiasi ir kvèpavimas. Straipsnyje nagrinejjami veiksniai, kurie turi j̨takos miegančių sveikų žmonių kvèpavimui. Tyrimai rodo, jog amžius ir cheminès medžiagos bei vaistai, kaip antai alkoholis bei benzodiazepinai, slopina kvèpavimą, sumažina deguonies įsotinimą kraujyje, tuo tarpu lytis neturi ryškesnès įtakos kvejpavimui.

Miegas - periodiška sąlyginès ramybès būsena, kurios metu organizmas, iš dalies praradęs kontaktą su aplinka, aktyviai atkuria savo jègas. Svarbiausias miego bruožas, kuris atskiria ji nuo budrios būsenos, yra suvokimo pertrūkis. Kai žmogus miega, susilpnèja jo fiziologinès funkcijos, jis nemato in negirdi, išnyksta sąmoningas psichikos aktyvumas.

Miego klasifikacija:

- Aktyvus budrumas - žmogus guli atmerkęs akis, nustatomas greitas, mažos amplitudès bioelektrinis aktyvumas, akys ir vokai juda.

- Ramus budrumas - žmogus guli atsipalaidavęs, užsimerkęs, elektroencefalogramoje (EEG) matyti alfa pobūdžio (8-13 svyravimų per sekundę) bioelektrinis aktyvumas, akys nejuda.

- Lètasis miegas, kuris skirstomas iz keturias stadijas: I stadija - snaudimas (elektroencefalogramoje (EEG) užrašomos mažos amplitudès teta bangos, 3-7 svyravimai per sekundę);

II stadija - miego pradžia (EEG užrašomos verpstès - 5-6 bangu grupès, 12-14 svyravimu per sekundę bei K kompleksai - didelès amplitudès dvifazès lètosios bangos);

III stadija (letosios bangos, 2-4 svyravimai per sekundę, užima 25-50 proc. laiko);

IV stadija (delta bangos, 0,5-2 svyravimai per sekundę, užima 50 proc. laiko).

- Paradoksinis (aktyvusis) miegas (EEG užrašomi mišraus aktyvumo teta bangu epizodai (dar vadinami „pjūklo dantų bangomis“, nes jų morfologija trikampe ir susimaišę su alfa ritmo pupsniais), užima 20-25 proc. viso miego laiko, pastebimi greiti pavieniai ar dauginiai akių judesiai, raumenų tonusas išnykęs, trumpi raumenų iškrūviai), kurie skiriami $\mathfrak{i}$ fazinius ir toninius (skiriasi raumenų tonusu - ryški atonija ar faziniai, trumpi judesiai). Dèl greituc akių judesių šis miegas dar vadinamas REM miegu (angl. rapid eye movements, REM), o lètasis - NREM.

Miego mechanizmą, ypač lètojo ir greitojo miego fazių kaitą, reguliuoja smegenų kamieno branduoliai. Lètojo miego metu aktyvuojama gama aminosviesto rūgštis (GABA) bei serotoninerginè sistema, dalyvauja regimasis gumburas ( $N$. reticularis thalami), atsakingas už lètojo miego pradžią bei slopinantis cholinerginę impulsaciją, žievès antrojo sluoksnio nervinès ląstelès, atsakingos už delta bangų atsiradimą, smegenų kamieno siūlès branduoliai (iš ju sklindanti serotoninerginé impulsacija palaiko gilesnị miegą - delta miegą, regimojo gumburo žievès neuronų hiperpoliarizaciją) bei pagumburis (skatina prostaglandino $\mathrm{D}$, insulino, adenozino, DSIP (delta miegą indukuojančio specifinio peptido) gamybą). Paradoksinio miego metu veikia tilto ir pailgụjų smegenų branduolių struktūros (jos turi cholinorecepsinius neuronus IV skilvelio dugne ir per serotoninerginę bei noradrenerginę sistemas aktyvinama žievė bei sukeliama raumenu atonija), keturkalnis (atsakingas už fazinio paradoksinio miego aktyvinimą), pagumburio ir hipofizio struktūros (susijusios su neuromoduliaciniu peptidu sekrecija) bei humoraliné sistema (išskirianti egzo- ir endogenines medžiagas: hormonus, peptidus ir kt.).

Miegas būtinas sveikam kūnui ir protui. Jis padeda kūnui pailsèti ir atsinaujinti visoms sritims:

- Atmintis, mokymasis ir socialiniai procesai - miegas padeda smegenims užkoduoti naują informaciją ir tinkamai ją saugoti. Neramus miegas aktyvina smegenų dalis, kurios kontroliuoja mokymąsi. Sme- 
genų dalys, kurios kontroliuoja jausmus, emocijas, sprendimų priemimą ir socialines sąveikas, miegant sulètèja.

- Nervų sistema - miegant atsikuria neuronų funkcijos. Kai žmogui miego stinga, nervų sistema negali funkcionuoti efektyviai, todèl susilpnejja.

- Imuninè sistema - miegas padeda imuninei sistemai efektyviai funkcionuoti. Jei miegama per mažai, imuninè sistema susilpnèja ir organizmas tampa jautresnis infekcijoms ir ligoms.

- Augimas ir raida - vaikams reikia daug daugiau miego negu suaugusiesiems. Augimo hormonai atsipalaiduoja miegant, todèl miegas yra gyvybiškai svarbus deramai fizinei ir protinei raidai.

Miegant susilpnejja daugelis organizmo funkcijų. Viena jų - kvėpavimas. Kvėpavimas - tai nenutrūkstantis biologinis procesas, kurio metu kvėpavimo organai ir kvèpavimo takai dalyvauja pasisavinant deguoni ir pašalinant anglies dioksidą. Jis keičiasi priklausomai ir nuo miego stadijos: pirmai lètojo miego stadijai būdinga nestabili kvépavimo kontrolè, o per kitas lètojo miego stadijas kvejpavimas tampa reguliarus, sumažèja kvèpavimo raumenuc tonusas, gali pagilèti hipoventiliacija. Faziniam paradoksiniam miegui būdingas nereguliarus, paviršinis kvejpavimas. Šio miego metu diafragma yra vienintelis kvejpavimo raumuo, dalyvaujantis kvépavimo procese, nes dèl bendros raumenų atonijos, kuri būdinga faziniam paradoksiniam miegui, tarpšonkauliniai krūtinès raumenys kvėpuojant nedalyvauja. Toniniam paradoksiniam miegui būdingas reguliarus, bet tai pat diafragminis kvėpavimas.

Kas dar turi įtakos miegančių sveikų žmonių kvèpavimui? Vienas iš miego tyrimo būdų yra polisomnografija. Ja ivertinama:

- smegenų bioelektrinis aktyvumas (EEG);

- akių obuolių judesiai;

- apatinio žandikaulio raumenų aktyvumas;

- knarkimas;

- kojuc raumenuc aktyvumas ir judesiai;

- širdies veiklos parametrai (EKG) ir pulso pokyčiai;

- deguonies ísotinimo kraujyje pokyčiai.

\section{VEIKSNIAI, VEIKIANTYS KVĖPAVIMĄ MIEGANT}

Lytis. Lyginant vyrų ir moterų kvėpavimo dažni bei kvépuojamąji tūrị miego metu, skirtumų nenustatyta, tačiau vyrams būdingesnis viršutinių kvèpavimo takų pasipriešinimas. Manoma, jog šie skirtumai atsiranda dèl moteriškųjų hormonu poveikio kvėpavimo taku plètikliams. Daugiausia hormonų būna liuteininèje fazèje, jų kiekis sumažèja folikulinèje fazèje ir ypač po menopauzès. Vyrams dažnesni deguonies ísotinimo sumažèjimo kraujyje epizodai tiek greitojo miego, tiek lètojo miego fazių metu. Dauguma tyrimų lyčių įtakos kvèpavimo kokybei miego metu nenustatè. Kadangi dažnesni deguonies ísotinimo sumažèjimo epizodai miegant nustatomi žmonėms, turintiems antsvorio, manoma, kad kokybiškesnis moterų miegas gali būti siejamas su mažesne moterų kūno mase.

Amžius. Dèl centrinès nervų sistemos brendimo, raumenų bei kremzlių formavimosi naujagimių, kūdikiu bei vaikų kvėpavimo sutrikimai skiriasi nuo suaugusiųjų, o paauglių kvèpavimo pokyčiai miego metu yra panašūs ị suaugusiųjų. Tiriant sveikus suaugusius žmones nustatyta, kad sumažèjęs deguonies įsotinimas ir periodinis kvèpavimas būdingesni vyresnio amžiaus žmonèms. Keleto tyrimų, kuriais tirti sveiki, jokių nusiskundimų dèl kvèpavimo sistemos neturintys vyresni nei 55 metų žmonès, duomenimis, nuo 30 iki 60 proc. tiriamųjų buvo požymių, kurie atitiko miego apnejos (kvėpavimo pauzè, atsirandanti miegant ir trunkanti mažiausia 10 sekundžių) sindromo kriterijus - daugiau nei 5 apnèjos ar kvépavimo sutrikimo epizodai per vieną miego valandą. Apnèja, nustatyta vyresnio amžiaus žmonèms, buvo tiek obstrukcinè (atsiradusi dèl viršutiniu oro taku pokyčių), tiek centrinè (atsiradusi dèl nervinès kvėpavimo kontrolès sutrikimų), jų trukmé nesiskyrè nuo apnëjos epizodų trukmès žmonių, kuriems diagnozuotas obstrukcinès miego apnèjos sindromas. Nustatytas ir didelis panašumas pagal deguonies ịsotinimo sumažejjimo kraujyje epizodų skaičių bei deguonies įsotinimo sumažejjimo laipsni. Kyla klausimas - kodẻl miego apnėja vyresnio amžiaus žmonėms nesukelia pastebimo poveikio sveikatai? Jie ne tik kad nejaučia simptomų, kuriuos turètuc sukelti miego apnèjos sindromas, bet ir nebūna pasekmių ateityje. Miego apnejjos išsivystymo mechanizmas vyresnio amžiaus sveikiems asmenims kol kas nėra aiškus. Nenustatyta ryšio tarp kūno masės, padidejjusio viršutinių kvėpavimo takų pasipriešinimo ir chemoreceptorių jautrumo. Manoma, kad tam turi ittakos endokrininès sistemos sutrikimai, alkoholio bei migdomųjų vaistų vartojimas. Minutinio kvėpavimo tūrio sumažejimas miegant buvo vienodas ir vyresnio amžiaus žmonių, kuriems nustatyta miego apnèjų, ir tų, kuriems jų nenustatyta, taip pat ir vyresnio, ir jaunesnio amžiaus žmoniu grupèse. Tai rodo, kad ventiliacijos sumažèjimas nepriklauso nuo apnejuc atsiradimo vyresniame amžiuje. Taip pat šiems žmonèms nepadideja ventiliacija reaguojant $i$ chemines medžiagas. Manoma, kad svarbiausias veiksnys, sukeliantis kvėpavimo nestabilumą vyresnio amžiaus žmoniu grupèje, yra padidèjęs miego jautrumas. Tai ir sąlygoja tiek centrinès, tiek obstrukcinès apnèjos išsivystymą, tačiau nesukelia klinikinių simptomų.

Nèštumas. Dèl sumažejusios funkcinès kvèpavimo talpos ir liekamojo tūrio, kaip ir dèl sumažejjusio širdies nuosrūvio gulint ant nugaros, nėščios moterys galètų patirti didesnę hipoksemiją miegodamos, tačiau, tiriant 36 savaites nèščias bei jau pagimdžiusias moteris, ryškesnių skirtumų miego metu nenustatyta, bet hipopnèjos ir apnejjos buvo retesnès nėščiųju grupeje, galbūt dèl stimuliuojančio progesterono poveikio kvėpavimo sistemai.

Cheminès medžiagos. Miegant kvėpavimą veikia daugelis vaistų ir cheminių medžiagų - vieni ji slopina, kiti aktyvina. Panagrinèsime dažniausia vartojamas chemines medžiagas - alkoholị ir benzodiazepinus.

Alkoholis kvėpavimą slopina nestipriai, tačiau jis padažnina miego apnèjų atsiradimą. Jo poveikis aiškinamas centrinès nervų sistemos bei viršutinių kvėpavimo takų raumenų jautrumo miegant slopinimu, dèl ko padideja ryklès pasipriešinimas. Šią nuomonę palaiko ir pastebejjimas, kad alkoholis sukelia ar sustiprina knarkimą - būklę, lemiamą padidejjusio oro srauto ir sumažejusio viršutinių kvępavimo takų tonuso. Nedidelio laipsnio alkoholinè intoksikacija 50 proc. sumažina ventiliacijos atsaką i hiperkapniją ir hipoksiją. Ti- 
riant 20 besimtomiu $20-65$ metų vyrų, nustatyta, kad, jiems pavartojus alkoholio, gerokai padaugèjo apnejos bei deguonies įsotinimo sumažejimo epizodų, pailgejjo apnèjos bei hipopnèjos trukmè, tačiau moterims (net pomenopauzinio amžiaus) tokio poveikio nebuvo. Kai kuriais tyrimais lygintas alkoholio poveikis jauniems, knarkiantiems ir sveikiems vyrams. Skirtumų nebuvo pastebèta arba jie buvo menki. Tokie nevienodi rezultatai aiškinami tiriamu grupių skirtingumu. Tuo tarpu tiriant vyresnio amžiaus, antsvorio turinčius vyrus alkoholio poveikis buvo akivaizdus. Alkoholio poveikis sveikų žmonių kvėpavimo funkcijai yra palyginti švelnus, o jo pavartojusiems vyrams, kuriems diagnozuotas obstrukcinis miego apnejos sindromas, apnèjos epizoduc padaugèja, pailgejja jų trukmè.

Taigi alkoholio poveikis yra trejopas:

1. Neknarkiantys pradeda knarkti;

2. Knarkiantiems atsiranda apnejja;

3. Esant obstrukcinès miego apnèjos sindromui, jis dar pasunkèja.

Daugelis raminamųjų vaistų veikia panašiai kaip alkoholis - svaigina. Vartojami siekiant slopinti nerimą, depresiją, gerinti miegą. Šiu preparatų negalima vartoti kartu su alkoholiu, nes poveikis stiprejja ir yra sunkiai prognozuojamas.

Benzodiazepinai - vieni dažniausiai vartojamų migdomųjų vaistų. Jų poveikis sveikų žmonių kvėpavimui nèra labai stiprus, tačiau sergantiems lètine obstrukcine plaučių liga (LOPL), esant ryškiai hiperkapnijai, organizmo jautrumas šiems vaistams padideja. Jie veikia taip pat kaip alkoholis - mažina viršutiniu kvejpavimo takų tonusą. Intraveninis midazolamas $(0,1$ $\mathrm{mg} / \mathrm{kg}$ ) sveikiems vyrams didina viršutinių kvėpavimo taku pasipriešinimą, sukelia tiek centrinè, tiek obstrukcinè apnèją. Tuo tarpu, kaip ir alkoholis, moterims vaistas poveikio nedaro. Manoma, kad jautrumas benzodiazepinams individualus, tačiau žmonèms, kuriems nustatytas obstrukcinès miego apnèjos sindromas, rekomenduojama šių vaistų neskirti. Centrinès apnèjos atsiradimo priežastys ịvairios. Keleto tyrimų duomenimis, asmenims, vartojusiems benzodiazepinus, sumažèjo centrinès apnèjos epizodų skaičius. Toks rezultatas gautas gydant klonazepamo $1 \mathrm{mg}$ nakčiai vieną savaitę prieš tyrimą. Kitas tyrimas rodo, kad, skyrus gydymą triazolamu $(0,125 \mathrm{mg}$ ar $0,25 \mathrm{mg} / \mathrm{d})$ penkiems sveikiems vyrams, kuriems vyravo centrinè apnejja, palyginti su placebu, 50 proc. sumažèjo apnejjos epizodų skaičius, daugiausia centrinių, tuo tarpu obstrukciniu nepakito. Žalingas alkoholio bei benzodiazepinu poveikis kvėpavimui pasireiškẻ ne visiems tirtiems asmenims. Kyla klausimas - ar žmonès nevienodai jiems jautrūs, o gal miego apnejos sindromo būta slapto ir vartojant šias medžiagas jis išryškejjo. Benzodiazepinus saugu skirti daugumai pacientų, kuriems diagnozuotas lengvo ar vidutinio laipsnio miego apnejjos sindromas ar LOPL be hiperkapnijos.

Narkotinės medžiagos smarkiai slopina kvėpavimą. Skyrus vienkartinę $10 \mathrm{mg}$ morfino dozę sveikiems asmenims, 40-60 proc. sumažèjo kvėpavimo sistemos atsakas ị hipoksemiją bei hiperkapniją bei $\mathrm{PCO}_{2}$ kiekis kraujyje padidejo nuo 2 iki $3 \mathrm{~mm} \mathrm{Hg}$. Narkotiniu medžiagu poveikis kvėpavimui miegant nèra gerai ištirtas. Kvèpavimą slopina ir centrinę nervų sistemą veikian-

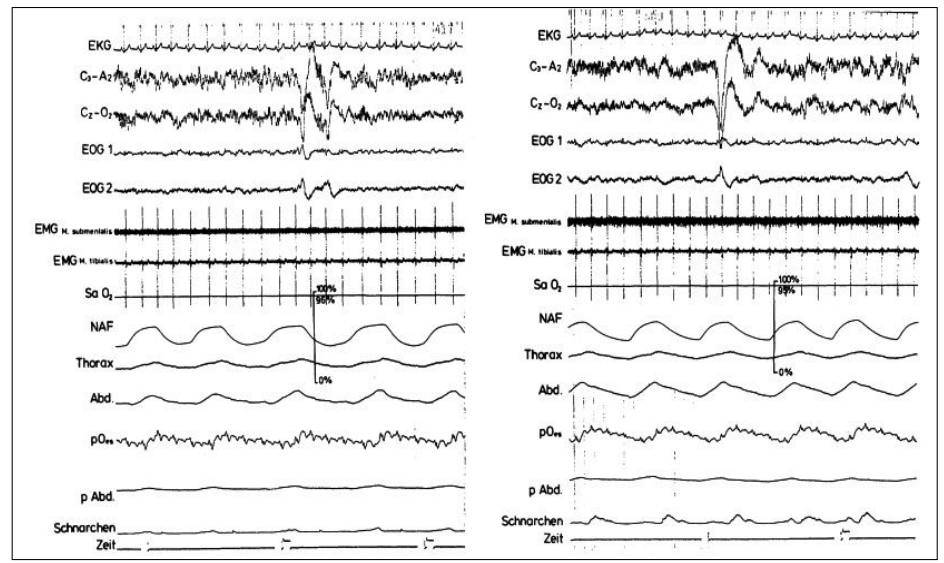

Pav. FLUNITRAZEPAMO (BENZODIAZEPINO) POVEIKIS KVËPAVIMUI MIEGANT, PALYGINTI SU PLACEBU

Dešineje - polisomnograma, užrašyta skyrus placebo. Atkreipti dèmesi: nèra knarkimo (14 kanalas), slègio svyravimai stemplèje tarp -5 ir $-7 \mathrm{~cm} \mathrm{H} \mathrm{H}_{2} \mathrm{O}$ (12 kanalas). Kaireje - tyrimas atliktas tam pačiam asmeniui skyrus flunitrazepamo, polisomnograma rašyta tos pačios miego fazès metu, esant tokiai pačiai kūno padèčiai. Atkreipti demesi:yra knarkimas (14 kanalas), slègis svyruoja tarp -12 ir - $15 \mathrm{~cm} \mathrm{H}_{2} \mathrm{O}(12$ kanalas). 1 kanalas - EKG (elektrokardiograma), 2 ir 3 kanalai - EEG, 4 ir 5 kanalai okilogramos, 6 kanalas - smakro raumeny elektromiograma (EMG), 7 kanalas - $m$. tibialis anterior EMG, 8 kanalas - pulsoksimetrija, 9 kanalas oro patekimas pro nosị ir burną, 10 kanalas - krūtinès judesiai, 11 kanalas pilvo judesiai, 12 kanalas - slègis stempleje, 13 kanalas - slègis pilve, 14 kanalas mikrofonas knarkimui registruoti, 15 kanalas - laikas. BK - balso klostès.

tys anestetikai bei antidepresantai, o tokios cheminès medžiagos kaip nikotinas, teofilinas, acetozolamidas ir almitrinas kvėpavimą stimuliuoja.

Taigi miegas yra susijęs su aiškiais sveiku žmonių kvėpavimo funkcijos pokyčiais. Ar šie pokyčiai atlieka specifinę funkciją vis dar neaišku, kol kas nesuprastos ir visos miego funkcijos. Ventiliacija miegant lengvai sutrikdoma, jai būdingas nestabilumas, yra pavojus, kad išsivystys viršutinių kvėpavimo takų obstrukcija, hipoventiliacija, sutriks ventiliacija ir perfuzija, o tai pažeidžia organizmo homeostazę.

\section{FACTORS INFLUENCING BREATHING DURING SLEEP OF NORMAL SUBJECTS}

\section{ASTA JANUŠKEVIČIUTTE PANEVËŽYS HOSPITAL}

Key words: sleep, sleep stages, breathing during sleep, sleep apnea. Summary. Sleep is essential for human body. Regular sleep is necessary for survival. During sleep physiological functions of body seared, people can't see and listen, breathing changes. In this article some factors, which influence breathing during sleep in normal subjects have been reviewed. Several studies have demonstrated that age and chemical substances, such like alcohol and benzodiazepines, depresses breathing, worsens saturation. No significant differences between genders concerning breathing during sleep have been shown.

\section{LITERATŪRA}

1. Miegas. Iš Vikipedijos laisvoji enciklopedija [interaktyvus]. Vikipedija, 2008. Prieiga per internetą <http://lt.wikipedia.org/wiki/Miegas.

2. Miliauskas $\mathrm{S}$. Kvejpavimo sutrikimu miego metu diagnostika ir gydymas. Kaunas $2007 \mathrm{~m}$.

3. LiesienèV, Pauza V. Miego medicina. Kaunas $1999 \mathrm{~m}$

4. Manber R, Armitage R. Sex, steroids, and sleep: a review. Sleep. 1999; 22:540-555.

Kiti literatūros šaltiniai - redakcijoje (iš viso 17). 